\title{
Towards an Integrated School Geography Curriculum: The Role of Place-based Education
}

\section{Lesley le Grange \\ Krystle Ontong}

\begin{abstract}
In this article, we review literature on curriculum changes to school Geography in post-apartheid South Africa. We note the gains and losses with each iteration of the national curriculum for school Geography over the past two decades or so. We argue that although the latest version, the CAPS has been strengthened in terms of continuity and progression it still has shortcomings: integration in the curriculum is weak, Indigenous Knowledge is not valued and its reliance on textbooks is likely to foster behaviourist pedagogical practices. We propose place-based education as a conceptual framework and approach to address current weaknesses in school Geography in South Africa so as to imagine the practice differently.
\end{abstract}

Keywords: CAPS, curriculum reform, curriculum integration, Indigenous knowledge, place-based education, school Geography

\section{Introduction}

There is a growing body of literature that has been produced on school Geography in post-apartheid South Africa. Our interest in this article is on the broader curriculum debates captured in this literature and in particular on those relating to the different iterations of the national curriculum, since the introduction of Curriculum 2005 in 1997, up to and including the Curriculum Assessment and Policy Statement (CAPS) published in 2011. We shall show 
that although the integrity of Geography has been strengthened over time, and so too continuity and progression across grades in the most recent version, the CAPS, there might still be several shortcomings such as that:

- the content of the curriculum is compartmentalised, thwarting efforts to integrate learning;

- the curriculum is textbook-based limiting possibilities for promoting constructivist learning;

- the inclusion of indigenous knowledge systems has been weakened (compared to some earlier iterations); and

- the term place has been constructed in mainly technical terms, as a natural construct rather than a social construct.

We explore the potential that place-based education as an approach could have in addressing shortcomings in the CAPS for Geography, were the approach to be understood and implemented by Geography curriculum makers, teacher educators and teachers.

A critical assessment of the CAPS for Geography has to, however, be contextualised within curriculum reform that has occurred in post-apartheid South Africa. Moreover, curriculum reform that occurs over time inevitably leads to gains and losses as curriculum changes occur with each new iteration of a national curriculum. Therefore, by way of background we shall review key changes that occurred to the national curriculum for school Geography over the past two decades or so, noting the key losses and gains with each version of the curriculum.

\section{National Curriculum Change and School Geography}

The first post-apartheid national curriculum framework was called Curriculum 2005 , which indicated the final year that the new curriculum was intended to be implemented in all school grades (Le Grange 2000). In some senses the curriculum marked a radical departure from the apartheid curriculum and its post-apartheid modification, NATED $550^{1}$. Other than its most contested

${ }^{1}$ NATED 550 was an interim syllabus (1995 - 1997) that was a modification of the apartheid syllabus. The modifications involved removing offensive content from syllabi such as racial content. 


\section{Lesley le Grange \& Krystle Ontong}

element outcomes-based education (OBE) (Le Grange 2010), Curriculum 2005 proposed a shift from a subject-centred approach to a more holistic learnercentred approach organised around integrated learning areas. This shift proposed the relinquishing of a primary reliance of textbooks as curriculum resource to the use of a range of curriculum resource materials of which textbooks could be one. Geography, had its 'home' in an integrated learning area called, Human and Social Sciences. This new arrangement elicited differing views from geography educators in South Africa at the time. Nel and Binns (1999) argued that this new arrangement placed school Geography in a precarious position in the sense that geographers were struggling to define Geography's identity within the newly established learning area in the General Education and Training (GET) band. They further expressed a concern about uncertainty as to whether Geography would be a separate subject in the Further Education and Training (FET) band. Curriculum 2005 was, however, aborted before it was implemented in the FET band, thus removing the latter concern. Ballantyne (1999) raised a concern about the implementation of the integrated learning area, arguing that teachers with a History background would foreground History in the classroom and those with a background in Geography would foreground Geography, potentially resulting in the dilution of either subject in specific classrooms. In relation to this concern, Binns (1999) points out that where integrated learning areas have been introduced in countries such as Australia and the United States of America (USA), Geography educators struggled to regain the subject's identity. In contrast, Van Harmelen (1999) took a more positive stance towards the changes that Curriculum 2005 introduced. She argued that Curriculum 2005 provided radical opportunities to rethink Geography education in South Africa by breaking away from textbook-based behaviourist approaches to school Geography. Van Harmelen averred that Curriculum 2005 opened up possibilities for social constructivist approaches to Geography education. About the FET Geography curriculum (NATED 550) that was still in place when Curriculum 2005 was implemented in the GET, Nel and Binns (1999) argued that this syllabus was dominated by thinking of western academic Geography, with a strong Eurocentric focus, reflecting the traditional values of 'White' South Africa.

In 1999 a committee was appointed by the Minister of Education to review Curriculum 2005, giving geographers and Geography teachers opportunities to forward submissions so as to strengthen the position of school 
Geography (Le Grange \& Beets 2005). The upshot of this was the buttressing of the distinctive character of Geography in the Revised National Curriculum Statement (RNCS) for the GET band and the reinforcing of Geography as one of 29 distinctive subjects of the National Curriculum Statement (NCS) in the FET band. However, although the distinctive identity of Geography was gained in the newly named GET Social Sciences learning area by having learning outcomes and knowledge foci separate from that of History, Physical Geography remained located in the Natural Sciences learning area and defined by the scope statement of the theme The Planet Earth and Beyond (Le Grange $\&$ Beets 2005). Concerning the FET, Le Grange and Beets (2005) pointed out that even though Geography was a distinct subject, it was located in the human and social studies learning field ${ }^{2}$. The implication of Geography's location in only one learning field meant that even though the rules of combination allowed for it to be offered as both a core and elective subject, the probability of it being offered as a core subject in schools was reduced (for a more detailed discussion see Le Grange and Beets 2005). About Nel and Binns's criticism that the NATED 550 Geography syllabus was Eurocentric, Le Grange and Beets (2005) point out that Indigenous Knowledge was included as one of the principles on which the NCS was based, registering the possibility for Geography teachers to include Indigenous Knowledge in the learning programmes they designed, and by so doing potentially decentering western approaches to school Geography. In short, the gains that the transition from Curriculum 2005 to the NCS brought about were the strengthening of Geography's identity in both the GET and FET and in the case of the FET the inclusion of Indigenous Knowledge. However, the NCS for Geography in the GET and FET still had weaknesses; a discussion to which we now turn.

In two articles Beets and Le Grange $(2005,2008)$ demonstrate that even though continuity and progression did improve in some respects in the transition from Curriculum 2005 to the RNCS and the NCS, there were still instances where these dimensions of curriculum design were weaker when compared to Curriculum 2005. Moreover, in areas where continuity and progression had been improved the documents provided insufficient information for teachers to design learning programmes that would ensure the incorporation of continuity and progression (Beets \& Le Grange 2005).

${ }^{2}$ The NCS of the FET band had six learning fields from which the 29 subjects were derived. 


\section{Lesley le Grange \& Krystle Ontong}

Continuity relates to the persistence of certain significant features of geographical education (in this instance) as a learner moves across grades in the schooling system. These significant features include: content, types of learning activity, common assumptions about the nature of the subject, geographical skills and use of certain resources (Beets \& Le Grange 2008). Progression (also called sequencing) is concerned with the careful and deliberate sequencing of learning so that learners can build on their prior learning and prepare for their future learning. It is this dimension that depicts the deepening of learning as learners move across grades. Beets and Le Grange (2008) point out that this is not a simple exercise and requires careful planning and a valid understanding of learners' actual and potential levels of performance. This brings us to the most recent iteration of the NCS, the CAPS. The Curriculum Assessment Policy Statement (CAPS) was produced in 2011 and phased into schools in 2012. The CAPS saw the removal of outcomesbased education (OBE), following sustained critiques of this approach to education (see Jansen 1998; Jansen \& Christie 1999; Le Grange 2000; 2008; 2010; Morrow 2007; Allais 2007; Shalem \& Pendlebury 2010). Le Grange (2014), however, argues that outcomes were simply replaced by aims and that the CAPS and all other versions of post-apartheid national curriculum frameworks for schools are neo-Tylerian ${ }^{3}$.

The CAPS for Geography in the GET and FET were clearly developed to strengthen continuity and progression (see DBE 2011). Evidence of this, in the case of the FET band, is found in a comprehensive demonstration of continuity and progression (in particular) in a recently published chapter by Golightly and Van der Westhuizen (2017). But, the CAPS also introduced some other elements. It is much more prescriptive than earlier iterations of the national curriculum for schools in the sense that it dictates when, how and for how long teachers must teach different topics (Le Grange 2014). The introduction of the CAPS also saw a return to a textbook-based curriculum that was last evidenced in the NATED 550 interim syllabi.

Continuity and progression are issues of verticality. In other words, they are respectively concerned with the persistence of features and depth in learning as learners progress vertically through the schooling system (from grade $\mathrm{R}$ to 12 ). However, there is another curriculum development/design

${ }^{3}$ Derived from the four principles of curriculum development produced by Tyler (1949). 
dimension that is an issue of horizontality, called integration ${ }^{4}$. Integration as a curriculum design principle is a twentieth century phenomenon that might have some of its origins in progressivist education exemplified in the work of John Dewey who argued for the integration of school and society, and the integration of the curriculum with the life world of the child (Dewey 1902; 1915). Nsubuga (2009) argues that in South Africa, we first saw evidence of integration occurring with the People's Education Movement, where attempts where made to integrate theory and practice, and head and manual work. In relation to curriculum design Le Grange and Reddy (2017) state that integration relates to how different curriculum components (including content) are associated with/to each other horizontally so as to give learners a unified rather than atomised sense of knowledge. The extent to which the CAPS for Geography promotes integration is a relatively unexplored area in the literature. For the purposes of this article, we shall focus on the integration of different components of the CAPS curriculum for FET Geography to provide learners with a sense of wholeness; and integration of schooling with the life world of the learner (the places learners inhabit and that inhabits them).

Moreover, the return to a textbook-based curriculum is likely to encourage behaviourist-teaching practices and thwart social constructivist pedagogies that Van Harmelen (1999) celebrated with the introduction of Curriculum 2005. Although Indigenous Knowledge continues to feature in the CAPS for Geography it is only mentioned twice in the FET document (DBE 2011), which means that it could easily be ignored by teachers if not assessed in the national senior certificate examinations, for example. Nel and Binns's (1999) concern of a Eurocentric Geography curriculum for South Africa might therefore not yet be allayed.

In summary, curriculum reform in relation to school Geography has had both gains and losses. The CAPS for both the GET and FET show that continuity and progression has been strengthened and that the identity of Geography in both these curriculum statements has been solidified. Though, not without challenges (lack of resources and training of teachers in many schools), the inclusion of Geographical Information Systems (GIS) in the FET curriculum is viewed positively because it has proved to be a successful sphere

${ }^{4}$ Not all curriculum scholars hold that curriculum integration is a matter of horizontality. For example, Muller (2000) views progression as a form of vertical integration. 


\section{Lesley le Grange \& Krystle Ontong}

of study and application (Manik 2016). However, there remains several shortcomings in the CAPS for Geography: the extent to which integration has been achieved remains largely unexplored; a return to a textbook-based curriculum could encourage behaviourist pedagogical approaches; and the weakening of the inclusion of Indigenous Knowledge systems when compared to earlier incarnations of the national curriculum, could reinforce a Eurocentric curriculum. Against this backdrop, in this article we shall investigate the extent to which integration is evident in the CAPS for FET Geography by focusing on the construct place, which is according to the CAPS document one of 'Geography's four Big Ideas' (DBE 2011: 7). We shall also explore the extent to which an integrated idea of place is evident in questions that appear in the national senior certificate (NCS) examination question papers. The latter will be done because we hold the view that what is assessed (particularly in highstakes examinations) is likely to determine teaching practices in classrooms. We shall also explore possibilities that place-based education might offer to strengthen integration in the FET Geography curriculum, strengthen the inclusion of Indigenous Knowledge systems in the curriculum and mitigate against behaviourist pedagogical practices. This brings us to a discussion on place and place-based education.

\section{Place and Place-based Education}

According to Cresswell $(2004 ; 2008)$ the concept of place derived from Geography in the 1950s and gained prominence in the discipline during the late 1970s and 1980s. He asserts that, even though 'place' could be deemed a meaningful theoretical terrain, it remains a difficult term to conceptualise because of its multiple meanings in various contexts. However, a multiple or expanded notion of place could be celebrated. For example, Gruenewald (2003: 619) argues for a multidimensional view of place comprising the perceptual, ideological, sociological, ecological and political dimensions (for a more detailed discussion on this see Ontong \& Le Grange 2015, 2016). Albeit that various geographers claim that place represents a sort of bounded space, Malpas (2016) argues, that its bounds do not take the form of dividing lines in space. According to him place is neither spatial nor temporal but encompasses both while refusing identification with either. He writes: 'to suppose otherwise would be to suppose that place somehow came after space, as a modification 
of it, whereas the reality is that it is place that comes first, and it is space that is the dependent phenomenon' (Malpas 2016: 384). Furthermore, Cresswell (2004) provides three fundamental aspects of place to distinguish between the term's technical meaning and daily usage, namely, place as area, locality and sense of place. In this article, we embrace an expanded notion of place instead of its representation in technical terms, i.e. as coordinates on a map. A technical view of place holds that it is synonymous with area and locality, and subordinate to space (Ontong \& Le Grange 2016).

Contending for an expanded and nuanced understanding of place is the interest of a recent development called place-based education. However, this discussion is not new to the field of Geography. Human geographers have long ago challenged the privileging of place in terms of scale, stressing that place/scale too are not given, but contingent, contested social constructs that are continually being made and remade. For example, Buttimer and Seamon (1980), Ley (1983), Relph (1976) and Tuan (1977) have reminded geographers that people do not live in a framework of geometric relationships, but in a world of meaning. Tuan (1977) avowed that place has no particular scale associated with it, but is created and maintained through the 'fields of care' which results from people's emotional attachment to it. Tuan (1977) specifically stressed the sensual, aesthetic and emotional dimensions of place. While, most (human) geographers have reached consensus that neither place nor scale is a fixed or given category, but socially constructed, fluid and contingent (Marston 2000), this understanding has not trickled down to the school curriculum. As Ontong and Le Grange (2016: 136) write: 'Even though geography as a discipline has progressed over the years, at school level the subject geography predominantly continues to focus on developing map skills among students ... while underemphasizing the other distinctions of place'. Gruenewald (2003) forcefully reminds us that if we fail to consider places as products of human decisions, we accept their existence as inevitable, like the falling of rain or the rise of the sun. Against the backdrop of our discussion of an expanded view of place, we turn to a discussion on place-based education.

Although the origin of placed-based education (PBE) could be traced back to the $17^{\text {th }}$ century, the idea has gained prominence over the past two decades (Ontong \& Le Grange 2016). Place-based education is an educational approach that embraces a multi-disciplinary approach to place (Gruenewald \& Smith 2008) and (re)connects humans with land (Knapp 2005). Woodhouse and Knapp (2000) aver that PBE embodies specific attributes of place, namely, 


\section{Lesley le Grange \& Krystle Ontong}

that it is inherently multidisciplinary, inherently experiential, reflects an educational philosophy that exceeds learning to learn, and connects place with the self and the community. According to Gruenewald and Smith (2008), the purpose of PBE is both to increase student engagement and achievement and to promote democratic participation in local community processes. Gruenewald (2003) states that place-based pedagogies are needed so that education of citizens might have some direct influence on the well-being of the social and ecological places that people inhabit.

The distinguishing feature of PBE, however, is not its specific methods (it draws from various pedagogic traditions), but rather its animating social purpose (Israel 2012). Through outdoor activities that engage learners with their community and natural environment, learners in place-based educational programmes learn about their place and learn to care for it: gaining knowledge and skills are inextricably connected with feeling and acting in new ways. With this connection between cognitive, affective, and ethical impacts upon learners, PBE provides a framework for making connections between content and pedagogy for socially engaged Geography teachers, offering a specifically geographic vision of ethically and politically engaged pedagogy (Greenwood 2013; Gruenewald 2003; Israel 2012; McInerney, Smyth \& Down 2011). Such learning cannot be textbook-based and occurs socially as learners engage with one another, communities and the natural environment. Through such engagement, new meanings are constructed in/about the places that leaners inhabit and that inhabit them. Moreover, PBE fosters an understanding of the oneness of people and places, a oneness between social and the natural (ecological) so that places are not studied as objects from a distant human gaze but that human knowledge (including learners' learning) are inextricably bound up with/in places. In short, place-based education does not only embrace a multidisciplinary perspective on place but also an integrated understanding of the concept.

Due to its emphasis on 'localness', PBE is inherently grounded in Indigenous Knowledge. Each place (incorporating people) has stories to tell or a dominant story to tell. As Tuck and Yang (2012) assert that Indigenous people have deep-rooted creation stories to share, not the ones told by colonisers. Yet, Greenwood (2013: 98) cautions that we need to devote attention not only to the dominant narratives, but also to 'all the stories at risk of being silenced or erased, including the voice of the land itself'. In the following section, we shall briefly describe the methodological framing of the empirical component of this article. 


\section{Methodological Approaches}

We shall use two research methods: a quantitative survey of documents and a qualitative content analysis of documents. The documents that will be surveyed and analysed quantitatively will be the CAPS for FET Geography (DBE 2011) and selected national senior certificate examination question papers for Geography. The survey of the CAPS will quantify the allocation of time per annum to the concept of place in the document. The qualitative content analysis will identify different units of meaning on place in the CAPS document to establish whether any units of meaning convey an integrated view of the concept. National senior certificate Geography question papers will be surveyed to quantify the percentage of the questions in the papers, which focus on the concept place. The qualitative content analysis of the examination question papers will identify whether the questions on place view place in atomistic terms or in an integrated manner.

The quantitative survey analysis comprises the following steps:

- An electronic search of the CAPS for FET Geography document to identify all references made to the word 'place';

- Highlighting references to the word 'place' in the following sections of the CAPS document: Overview of the Content in the FET band; Overview of the Geographical Skills and Techniques in Grades 10, 11, 12; and Geographical Knowledge;

- Calculating the teaching/learning time allocated to sections of the CAPS that make direct reference to the concept 'place';

- Determining the sum total of all questions in each of the NCS Paper 1 examinations for the years 2013 - 2017;

- Calculating the percentage of questions that are related to the concept 'place' for each of the NCS Paper 1 examinations for the mentioned years.

The qualitative content analysis comprises the following steps:

- Identifying units of meaning related to the concept 'place' in the CAPS document and the selected NCS Paper 1 examination papers;

- Interpreting units of meaning in relation to different understandings/ dimensions of place. 
The November National Senior Certificate (NSC) examination papers (2013 2017) for grade 12 will be selected for this study. These papers will be selected to not only get a general sense of the geographical knowledge that learners need to know at the end of their schooling career, but also to view how integration occurs and how place is represented.

\section{Analysis of Curriculum and FET Examination Papers CAPS Document}

In this section, we describe the extent to which the CAPS for Geography in the FET band makes reference to the concept place. Firstly, one of the nine aims of the CAPS Geography for the FET band makes direct reference to the concept place and reads as follows: 'developing knowledge about where places are, and the nature of a range of different places at different scales' (DBE 2011:9). Secondly, and most importantly the document states that any topic in Geography can be explored by applying a conceptual framework that embraces Geography's four big ideas: place; spatial processes, spatial processes; spatial distribution patterns; and human and environmental interaction (DBE, 2011: 9). The significance of the concept place is clearly emphasised in the CAPS for Geography in the FET band.

However, in the sections Overview of Geography Content in the FET band, Overview of Geography skills and Techniques in Grades 10, 11 and 12 and Geography knowledge (where time allocations are included) scant reference is made to the concept place. In the section Overview of Geography Content in the FET band there is not one direct reference made to the concept place under the listed topics. In the section Overview of Geography skills and Techniques in Grades 10,11 and 12 there is only one direct reference made to place in grade 11, under the topic Using atlases (revision), 'Locating places on different maps: degrees and minutes' (DBE 2011: 16). In the part of the document Geographical Knowledge, where all the main topics and sub-topics for grades 10-12 are listed, with allocated times that should be spent, direct reference to place is only made five times. In grade 10, direct reference to place is made once under the heading, Heating of the Atmosphere. This topic is allocated eight hours, with five sub-topics of which one sub-topic refers to place, 'factors that affect temperature of different places around the world: latitude, altitude, ocean currents and distance from oceans' (DBE 2011: 21). If equal time were to be spent in classrooms on each of the five sub-topics then only 96 
minutes per annum would be devoted to the sub-topic that refers to place.

With reference to Grade 11 there are two direct references made to place, under the topic Using Atlases (revision), which is allocated two hours. This topic has three sub-topics of which one makes direct reference to the concept place, 'locating places on different maps, using degrees and minutes' (DBE 2011: 29). If each of the three topics were to be allocated equal time in classrooms, then the one that refers to place will presumably be allocated $\mathbf{4 0}$ minutes per annum in classrooms. The same topic and sub-topics are included later in the document where one hour is allocated to the topic (DBE 2011:35). This means that an additional $\mathbf{2 0}$ minutes could be allocated to the sub-topic on place in Grade 11. Under Geographical Knowledge for Grade 12 there are two direct references made to the concept place. Under the topic Urban Settlements, to which four hours is allocated, there are three sub-topics and one refers to place, 'classification of urban settlements according to function, such as central places, trade and transport, break of bulk points, specialized cities, junction towns and gateway towns or gap towns' (DBE 2011: 45). If equal time were devoted to each of the sub-topics under Urban Settlements, then 80 minutes per annum of teaching/learning will be allocated to the subtopic, which refers to place. The last reference to the concept place in the part of the document that covers Geographical Knowledge is under the topic, Urban Hierarchies. This topic has three sub-topics and the one that refers to place reads as follows: 'the concepts of urban hierarchy, central place, threshold population, sphere of influence and range of goods'. The topic Urban Hierarchies is allocated two hours per annum, meaning that the sub-topic that refers to place will presumably be allocated $\mathbf{4 0}$ minutes per annum.

A few observations are worth noting. Firstly, direct reference to the concept place in the CAPS document is scant. Secondly, place appears to be treated in fragmented ways and there is no evidence of integration of place across topics or sections. Thirdly, in the document place is constructed in technical terms as coordinates on a map and as something that the human can study at a distance, as if detached from places. Fourthly, the rigid time allocation to topics and the compartmentalised structure of the topics in the document threatens to thwart efforts to integrate topics and their sub-topics. All of this is compounded by a curriculum that relies heavily on the use of prescribed textbooks.

However, we also analysed examination question papers to ascertain the coverage that the concept place enjoys and to ascertain to what extent the 
concept place is integrated in questions asked. We focus our analysis on the national senior certificate examinations because these are the only ones that are standardised in South Africa. Our assumption is that the nature of the questions in the NSC examinations will influence how teachers teach and what is taught. Moreover, that the type of questions asked in the NCS examinations will not only affect teaching in grade 12 , but that there will be a trickle-down effect to grades 10 and 11 .

\section{Examination Papers}

The grade 12 National Senior Certificate (NCS) examination for Geography consists of two papers (Paper 1 and Paper 2) with each one accompanied by an annexure containing all graphs, maps and visual representations. Paper 1 deals with Physical and Human Geography and totals 225 marks. The second paper comprises map work and GIS components, totaling 75 marks. Paper 1 is divided into two sections: section A comprises climate, weather and geomorphology; and section B comprises rural and urban settlements and South African Economic Geography. Learners are expected to answer at least one question in both sections and have a choice on the other two questions that they have to answer. Table 1 below represents the structure of the NCS examination for Geography in the FET band.

Table 1: Structure of the NCS examination for Geography in the FET band

\begin{tabular}{|c|c|c|c|c|}
\hline & $\begin{array}{r}\mathrm{Ge} \\
\text { National S } \\
\text { Grade } 12 \mathrm{Ex} \\
(30\end{array}$ & $\begin{array}{l}\text { raphy } \\
\text { ior Certificat } \\
\text { nination Pap } \\
\text { Marks) }\end{array}$ & & \\
\hline $\mathrm{Pa}$ & & & Paper 2 & \\
\hline Section A & Section B & & & \\
\hline $\begin{array}{c}\text { Weather, } \\
\text { Climate and } \\
\text { Geomorphology }\end{array}$ & $\begin{array}{c}\text { Rural and } \\
\text { urban } \\
\text { settlements and } \\
\text { South African } \\
\text { Economic } \\
\text { Geography }\end{array}$ & $\begin{array}{c}\text { Map } \\
\text { calculations } \\
\text { and } \\
\text { techniques }\end{array}$ & $\begin{array}{l}\text { Application } \\
\text { and } \\
\text { interpretation }\end{array}$ & GIS \\
\hline 225 & arks & & 75 Marks & \\
\hline
\end{tabular}


From the division into the two papers it is evident that Paper 2, which comprises $25 \%$ of the examination is solely based on the technical dimension of place (calculations, map interpretation, applications, etc.). Paper 2 is subdivided into map calculations and techniques, application and interpretation and GIS. Map calculations entail calculations of magnetic bearing, area and gradient among others. For example, a typical question in the 2016 November paper reads as follows, 'Calculate the average gradient between spot height $1306(\mathrm{~K})$ and trigonometrical station 101 (L). Show all calculations. Marks will be awarded for calculations' (DBE 2016: 7). A similar example appears in the 2017 Paper 2: 'Calculate the vertical interval (VI) between M and spot height 1395 in metres. Show all calculations. Marks will be awarded for calculations' (DBE 2017b:7). Our analysis shows that this was the standard format and type of questions found in Paper 2 for the years 2014 and 2015 as well. The emphasis is largely placed on calculations in Paper 2. Further evidence of this is the fact that learners are awarded with marks should they present all their calculations. This highlights how the technical dimension of place is focused on at the cost of other dimensions of place such as the sensual, aesthetic and emotional. In cases where learners are not expected to do calculations, the reasoning that they need to apply in order to answer the questions, remains technical in nature. For example, this is apparent in the following question asked in Paper 1 where students are expected to: 'describe one climatological disadvantage for people living in West End' [and to] 'give two points of evidence on the topographical map to substantiate the statement' (DBE 2017b: 12). Now, we turn to an analysis of Paper 1 to see to what extent the concept place is covered in the questions posed in the paper and to see whether place is presented in an integrated manner in the questions. Table 2 below represents the percentage of questions ${ }^{5}$ related to place asked in the NCS Paper 1 examination for the years 2013-2017 (DBE 2013; 2014; 2015; 2016; 2017a; 2017b).

Table 2: Percentage of questions related in 'place' in the NCS examination Paper 1

\begin{tabular}{|c|c|c|c|c|c|}
\hline Year & 2013 & 2014 & 2015 & 2016 & 2017 \\
\hline $\begin{array}{c}\text { Number of } \\
\text { questions }\end{array}$ & 121 & 153 & 139 & 147 & 146 \\
\hline
\end{tabular}

${ }^{5}$ Note that the questions here include all sub-questions which fall under the main questions learners have to choose from. 


\begin{tabular}{|c|c|c|c|c|c|}
\hline $\begin{array}{c}\text { Number of } \\
\text { questions related } \\
\text { to 'place' }\end{array}$ & 46 & 57 & 72 & 68 & 81 \\
\hline $\begin{array}{c}\% \text { of questions } \\
\text { related to 'place' }\end{array}$ & 38.02 & 37.25 & 51.79 & 46.26 & 55.48 \\
\hline
\end{tabular}

The relatively high percentage of questions related to place in the Paper 1 examinations we analysed for the years 2013 to 2017 is encouraging, given the fact that direct reference to the concept place in the CAPS for FET Geography is scant. This gives some credence to the statement in the CAPS for FET Geography that place is one of the big ideas of Geography. It also indicates that assessments and by implication curriculum materials as well as teaching and learning can be interpreted more broadly/liberally than what the curriculum document appears to convey - that assessors, teachers and textbook writers have agency. However, given the structure of the examination papers and the way in which geographical knowledge in the CAPS document is divided into different sections/components, questions on place remain mostly compartmentalised, and many questions on place represent the concept in technical terms and as having fixity. For example, in Paper 1, questions related to place in the grade 12 November 2014 NCS paper required of learners to answer the following: 'Define the term rural-urban migration. Give TWO push factors that result in rural-urban migration. Propose ONE way of preventing rural towns from becoming "ghost towns". ... There is a view that quality housing and employment opportunities are pull factors to urban areas. In a paragraph of approximately EIGHT lines, critically evaluate the extent to which this is true' (DBE 2014: 12). Although these questions relate to place, they are chiefly based on memory recall and do not reflect the multidimensionality of the concept. Nowhere are learners asked to explain the human's interaction/relationship to and the effects on the natural environment in these questions. People's attachment to places are also not emphasised, for example, how people feel when they have to leave home due to pull or push factors related to migration.

The seemingly disparate questions/themes discussed in the previous paragraph could, however, be integrated. The kind of calculations mentioned and the type of reasoning required in Paper 2 are important, but could be integrated with most of the themes in Paper 1. For example, some of the skills like calculating gradient, drawing cross sections, the notion of buffering in GIS 
and so forth could be integrated with Paper 1 under rural and urban settlements where more preference is given to the 'emplaced' human being. This would not only provide learners with a multidimensional view on the concept of place, but would also foster a more holistic and nuanced understanding of the concept. Based on the current organization of content in the NSC grade 12 examination papers, it can be said that place is represented as something divorced from the human being and which can be studied objectively from a distance. Though traces of the human's embeddedness in place can be seen in Paper 1, for example, '... evaluate how the inhabitants and their activities in informal settlements negatively affect the environment' (DBE 2016: 9), the rest of paper mainly requires technical reasoning and answers. For example, under climate, weather and geomorphology, students are asked to give answers to questions such as, 'state where the highest wind speed is recorded in the graph ... in which area does the tropical cyclone experience the lowest pressure?' (DBE 2016: 3).

There, are, however, questions in all of the NCS papers where some degree of integration can be observed in relation to the concept place. For example, the following questions asked in the 2013 NSC Paper 1 examination: 'Explain why people in KwaZulu-Natal would not have been prepared for the chaos created by tropical cyclone Irina. Give TWO reasons'; and 'Write a paragraph (approximately 12 lines) explaining the impact that the flooding caused by Irina would have on the economy and environment of KwaZuluNatal' (DBE 2013: 4). Here we see how the study of weather systems is integrated with the interests of people, the economy and the natural environment. Another example where an integrated notion of place might be evident is in the following questions asked in the NCS Paper 1 of 2014: 'What initiated the Marikana strike? ...'; 'State TWO safety hazards that the miners are exposed to ...'; 'Besides industrial activities, discuss why the instability at Lonmin's Marikana mine will impact negatively on the GDP ...'; How can the owners (Lonmin) of the Marikana mine improve working conditions at the mine? ...' (DBE 2014: 12). Here we see how mineral deposits in a certain geographical area of South Africa intersect with the economic activity of mining and with people's safety and livelihoods. It integrates aspects of geomorphology with Economic Geography and Human Geography (in particular rural and urban settlements). The questions also embrace a more expanded notion of place than viewing place in purely technical terms. Notwithstanding this, much of work related to the content of the questions 
would have been learned through use of textbooks, given that the CAPS is a textbook-based curriculum. The upshot of this is that learners view places as distant from themselves, their beliefs, interests and values. In other words, there is little room for leaners to engage with the places they know, the places they are attached to and which give meaning to their lives - the places they inhabit and that inhabit them. Innovative teachers, will of course find opportunities for learners to engage with/in local places and introduce pedagogies that will enable learners to understand place as multidimensional. Nevertheless, when a curriculum is as prescriptive that the CAPS is, then such opportunities might be rare.

None of the questions in the five NCS examination papers surveyed referred to Indigenous Knowledge, confirming our earlier point that even though Indigenous Knowledge is stated as a key principle of the CAPS, the principle may not be observed in all school subjects. Moreover, a prescriptive and textbook-based curriculum is likely to be concerned with transmission modes of teaching rather than social constructivist approaches. We suggest that placed-based education is an approach/framework to/for education that could address some of the shortcomings of the current school curriculum for FET Geography.

\section{Discussion}

Based on the analyses of both the CAPS and NCS examination papers, one may conclude that place is (re)presented in a fragmented rather than integrated manner. Compartmentalisation into the four branches of school geography manifests in the examination papers and by association possibly in the pedagogical practices of teachers as well. This situation is an impediment to geographical understanding; given Hurry's (2010) contention that holistic teaching and learning are key principles for fostering geographical understanding. Place-based education is an overarching approach that could integrate the different dimensions of place captured in the CAPS for FET Geography and the NCS examinations for the subject. This would require rethinking the pigeonholing of the different dimensions of place into particular divisions/sections of Geography and would give fuller credence to the view that place is one of the 'Big ideas' of Geography. The current way in which both the CAPS and the NCS is structured along specialist areas of the discipline Geography necessitates the raising of a critical question, what is school 
Geography for? Should school Geography mirror the traditional specialist areas of the academic discipline Geography ${ }^{6}$ or focus on developing Geographical knowledge and skills needed for learners to function as critical citizens in society? Our preference is for the latter view of schooling through place-based education aimed at developing a critical consciousness in/on/with place or places. A place-based approach to school Geography would mean that artificial divisions between a Paper 1 and Paper 2, as is currently the case with formal examinations, should be done away with. It is instructive to note that Geography Paper 2 (practical work in Geography) was introduced as part of the matric examination in South Africa as far back as the 1960s at a time when positivism had a strong influence on the discipline, and there was a strong alignment between school Geography and the study of academic Geography at university (Wesso \& Parnell 1992; Manik 2016). These reasons might not hold in a contemporary world that is faced with complex problems and that requires integrated and complex responses.

Place-based education embraces a multidimensional view of place, holds that place is a concept that is socially constructed, that subjectivities are bound up in places, and that both subjectivities and places are fluid, complex and performative. Humans' connections with places are 'intra-actions' (Barad 2007: 33) - humans' action in/on/with places are bound up in the places. Placebased education therefore implies new ways of knowing that cannot be textbook-based and abstracted from the places studied. Law (2004) is helpful in outlining alternative ways of knowing. Law (2004: 3) identifies four alternative ways of knowing: knowing as embodiment, knowing as emotionality and apprehension, knowing through deliberate imprecision, and knowing as situated enquiry. Knowing as embodiment is to know through the hungers, tastes, discomforts, or pains of our bodies. Knowing as emotionality is about opening ourselves to worlds of sensibilities, passions, intuitions, fears and betrayals. Knowing through deliberate imprecision is about rethinking our ideas about clarity and rigour, and about finding ways of knowing the indistinct and slippery without trying to hold them tightly. Moreover, knowing as situated enquiry is about rethinking how far knowledge is able to travel and whether it still makes sense in other locations. The ways of knowing that Law (2004)

${ }^{6}$ We refer here to traditional specialist areas of Geography typically taught in university courses, and not leading edge work done in the discipline of Geography on place, to which our ideas on place expressed in this article align. 


\section{Lesley le Grange \& Krystle Ontong}

open up are at the heart of place-based education, which emphasises people's oneness with places, their attachment to places, and that their knowledges are located in places. Place-based pedagogies cannot therefore be circumscribed to knowledge transmitted through textbooks, but should be about learning in interaction/intra-action with others (both human and non-human). The situatedness of all knowledge suggests that all knowledges are Indigenous, even those knowledge systems such as western science, which has the appearance of universal truth and whose cultural fingerprints might not be as conspicuous as those commonly referred to as 'indigenous knowledge' (for a detailed argument, see Gough 2003). Place-based education therefore values Indigenous Knowledge, recognising that no knowledge exists separate from places.

But, what might all of this mean for curriculum advisors, teacher educators and teachers in the field of Geography? We suggest that all involved in the Geography community might begin by familiarizing themselves with the multidimensionality of the notions of place and place-based education. Moreover, that these role players view place-based education as a potentially useful approach for overcoming the disintegration between the four branches of school geography, and concurrently promoting social constructivism. This could be achieved through embracing Marston, Jones and Woodward's (2005) proposal of a 'flat ontology' that draws on actor-network theory (ANT) and focuses on specific social sites of interaction (Schatzki 2002). Flat ontology is in contrast with the vertical hierarchy of place/scales and supports sites (contextual milieus composed of human and non-human practices and order) as the basic spatial entities upon which socio-spatial theorizing should be built. A flat ontology assumes that 'place' is always emergent and that sites are continually transformed through unfolding network connections with more wide-ranging spaces. Marston, et al. (2005) argue, that only through flat ontology will all scalar conceptual baggage be discarded. The proposals made in this article are radical and are in conflict with a prescriptive textbook-based curriculum, but a necessary challenge to all those with a stake in school Geography. A starting point could be to identify opportunities that the current curriculum provides for enacting some of these proposals. One such opportunity is in the CAPS document itself, the view that place is one of four Big ideas that any conceptual framework in Geography can be based on (DBE 2011: 8).

Closer to the classroom, a possibility worth exploring is for both teachers and teacher educators as a means to overcome the 'objectification' of 
place in the CAPS and examination papers could be through quick response $(\mathrm{QR})^{7}$ codes. The generation and integration of $\mathrm{QR}$ codes when teaching any theme (especially place) in Geography will not only enhance ICT in teaching and learning processes but will also make information on maps, graphs and other themes a reality for learners. In this way, synoptic and topographical maps and other geographical phenomena like hurricanes, plate tectonics and so on come 'alive' in real time and makes content relevant and easy to understand. QR codes are especially useful in cases where teachers experience challenges with out-of-the-classroom learning experiences/activities.

\section{Conclusion}

In this article, we reviewed literature on curriculum reforms in school Geography that have occurred in post-apartheid South Africa. We noted the gains and losses of each curriculum change. We argued that although the most recent version of the school Geography curriculum (the CAPS) has addressed shortcomings of previous post-apartheid curricula, it still has shortcomings: integration is relatively weak; the inclusion of Indigenous Knowledge has been considerably weakened; and a return to a textbook-based curriculum may foster undesirable behaviourist pedagogical practices.

We propose place-based education as an approach that can address these weaknesses in the current school curriculum. This approach holds the promise of integrating different components of Geography around one of Geography's big ideas, the concept place. Place-based education gives credence to what has become clichéd, 'all knowledge is socially constructed and situated' and therefore values Indigenous Knowledge. Moreover, because knowledge is the product of human intra-action with places, it cannot preexist such intra-actions with places and therefore cannot be textbook-based. Placebased education therefore provides a way of integrating schooling with the places learners inhabit and that inhabits them.

Place-based education as a framework for school Geography, suggests a radical departure from the status quo. Its adoption would of course not mean change overnight but a process of change that does present challenges for all those with a vested interest in school Geography. Taking up these challenges

${ }^{7}$ A quick response codes is a type of $2 \mathrm{D}$ code that is often used to provide information rapidly on a mobile phone. 
will not be easy and will 'inevitably involve sweat, personal risk, intellectual daring and inconvenience' (Orr 1992: 166), which may run counter to the modes which currently dominate school Geography curriculum practice.

\section{References}

Allais, S. 2007. Education Service Delivery. The Disastrous Case of Outcomes-Based Qualifications Frameworks. Progress in Development Studies 7, 1: 65 - 78.

https://doi.org/10.1177/146499340600700106

Ballantyne, R. 1999. An Analysis of Geography Teacher Educators' Perceptions of Curriculum 2005. South African Geographical Journal 81, 2: $75-79$.

https://doi.org/10.1080/03736245.1999.9713665

Barad, K. 2007. Meeting the Universe Halfway: Quantum Physics and the Entanglement of Matter and Meaning. Durham: Duke University Press. https://doi.org/10.1215/9780822388128

Beets, P. \& L. le Grange 2005. Continuity and Progression: The Achilles' Heel of the National Curriculum Statement for Geography. South African Journal of Education 25, 3: 190 - 197.

https://doi.org/10.1080/03736245.2008.9725315

Beets, P.A.D \& L. le Grange 2008. Has Geography Curriculum Reform in Post-Apartheid South Africa Strengthened Continuity and Progression? South African Geographical Journal 90, 2: 68 - 79.

Binns, T. 1999. Is Geography Going Places? South African Geographical Journal, 81, 2: 69 - 74.

https://doi.org/10.1080/03736245.1999.9713664

Buttimer, A. \& D. Seamon 1980. The Human Experience of Space and Place. London: Croom Helm Ltd.

Cresswell, T. 2004. Place: A Short Introduction. Malden, MA: Blackwell.

Cresswell, T. 2008. Place: Encountering Geography as Philosophy. Geography 93, 4: $132-140$.

Department of Basic Education (DBE) 2011. Curriculum and Assessment Policy Statement, Grades 10 - 12, Geography. Pretoria: Department of Basic Education.

Department of Basic Education (DBE) 2014. National Senior Certificate 
Examination Paper 1, Grade 12. Pretoria: Department of Basic Education.

Department of Basic Education (DBE) 2014. National Senior Certificate Examination Paper 2, Grade 12. Pretoria: Department of Basic Education.

Department of Basic Education (DBE) 2015. National Senior Certificate

Examination Diagnostic Report. Pretoria: Department of Basic Education.

Department of Basic Education (DBE) 2016. National Senior Certificate Examination Paper 1, Grade 12. Pretoria: Department of Basic Education.

Department of Basic Education (DBE) 2016. National Senior Certificate Examination Paper 2, Grade 12. Pretoria: Department of Basic Education.

Department of Basic Education (DBE) 2017a. National Senior Certificate

Examination Paper 1, Grade 12. Pretoria: Department of Basic Education.

Department of Basic Education (DBE) 2017b. National Senior Certificate

Examination Paper 2, Grade 12. Pretoria: Department of Basic Education.

Dewey, J. 1902. The Child and the Curriculum. Chicago: The University of Chicago Press.

Dewey, J. 1902. The School and Society. Chicago: The University of Chicago Press.

Golightly, A. \& C.P. van der Westhuizen 2017. Looking for Geographical Learning Progressions in the Schools. In Solari, O.M., M. Solem \& R. Boehm (eds.): Learning Progressions in Geographical Education: International Perspectives on Geographical Education. Urdorf: Springer. Gough, N. 2003. Thinking Globally in Environmental Education: Implications for Internationalising Curriculum Inquiry. In Pinar, W.F. (ed.): International Handbook of Curriculum Research. Mahwah, NJ: Lawrence Erlbaum Associates, Publishers.

Greenwood, D.A. 2013. A Critical Theory of Place Conscious Education. In Stevenson, R.B., M. Brody, J. Dillon \& A.E.J. Wals (eds.): International Handbook of Research on Environmental Education. New York: Routledge.

https://doi.org/10.4324/9780203813331.ch9 
Gruenewald, D.A. 2003. Foundations of Place: A Multidisciplinary Framework for Place-Conscious Education. American Educational Research Journal 40: 619 - 654.

https://doi.org/10.3102/00028312040003619

Hurry, L. 2010. Geography Teaching in Southern Africa: An Introductory Guide. Pretoria: Van Schaik Publishers.

Israel, A.L. 2012. Putting Geography Education into Place: What Geography

Educators can Learn from Place-Based Education, and Vice Versa. Journal of Geography 111, 2: 76 - 81.

https://doi.org/10.1080/00221341.2011.583264

Jansen, J.D. 1998. Curriculum Reform in South Africa: A Critical Analysis of

Outcomes-Based Education. Cambridge Journal of Education 28, 3: 321

- 331.

https://doi.org/10.1080/0305764980280305

Jansen, J.D. \& P. Christie (eds.) 1999. Changing Curriculum: Studies on

Outcomes-Based Education in South Africa. Kenwyn: Juta \& Co Ltd.

Knapp, C.E. 2005. The 'I-Thou' Relationship, Place-based Education, and Aldo Leopold. Journal of Experiential Education 27: 277 - 285.

Law, J. 2004. After Method: Mess in Social Science Research. London: Routledge.

Le Grange, L. 2000. Towards a Language of Probability in South African OBE Discourse. Education as Change 4, 1: 21 - 30.

Le Grange, L. 2007. (Re)thinking Outcomes-Based Education: From Arborescent to Rhizomatic Conceptions of Outcomes (Based-Education). Perspectives in Education 25, 4: 79 - 85.

Le Grange, L. 2010. South African Curriculum Studies: A Historical Perspective and Autobiographical Account. In Pinar, W. (ed.): Curriculum Studies in South Africa: Intellectual Histories, Present Circumstances. New York: PalgraveMacMillan Publishers.

https://doi.org/10.1057/9780230105508_6

Le Grange, L. 2014. Curriculum Research in South Africa. In Pinar, W. (ed.): International Handbook of Curriculum Research. Second Edition. New York: Taylor \& Francis.

Le Grange, L. \& P. Beets 2005. Geography Education in South Africa after a Decade of Democracy. Geography 90, 3: 267 - 277.

Le Grange, L. \& C. Reddy 2017. Curriculum Development and Design. In Ramrathan, L., L. le Grange \& P. Higgs (eds.): Education Studies for 
Teacher Development. Lansdowne: Juta.

Ley, D. 1983. A Social Geography of the City. New York, NY: Harper and Row.

Malpas, J. 2016. Placing Understanding/ Understanding Place. SOPHIA 56: 379 - 391.

https://doi.org/10.1007/s11841-016-0546-9

Manik, S. 2016. Tracing Geography Education's Footprints in South Africa. In Visser, G., R. Donaldson \& C. Seethal (eds.): The Origin and Growth of Geography as a Discipline at South African Universities. Stellenbosch: Sun Media.

Marston, S. 2000. The Social Construction of Scale. Progress in Human Geography 24: 219 - 42.

https://doi.org/10.1191/030913200674086272

Marston, S., J.P. Jones \& K. Woodward 2005: Human Geography without Scale. Transactions of the Institute of British Geographers 30: 416 - 432. https://doi.org/10.1111/j.1475-5661.2005.00180.x

McInerney, P., J. Smyt \& B. Down 2011. Coming to a Place Near You? The Politics and Possibilities of a Critical Pedagogy of Place-Based Education. Asia-Pacific Journal of Teacher Education 31, 1: 3 - 16.

https://doi.org/10.1080/1359866X.2010.540894

Morrow, W. 2007. Learning to Teach in South Africa. Cape Town: HSRC Press.

Muller, J. 2000. Progressivism Redux: Ethos, Policy, Pathos. In Kraak, A. \& M. Young (eds.): Education in Retrospect: Policy and Implementation since 1990. Pretoria: HSRC Press.

Nel, E. \& T. Binns 1999. Changing the Geography of Apartheid Education in South Africa. Geography 84, 2: 119 - 128.

Nsubuga, Y.N. 2009. The Integration of Natural Resource Management into the Curriculum of Rural Under-resourced Schools. Unpublished PhD thesis. Rhodes University.

Ontong, K. \& L. le Grange 2015. The Need for Place-Based Education in South African Primary Schools: The Case of Greenfields Primary. Perspectives in Education 33, 3: 5 - 20.

Ontong, K. \& L. le Grange 2016. Reconceptualising the Notion of Place in School Geography. Geography 101, 3: 137 - 145.

Orr, D. 1992. Ecological Literacy: Education and the Transition to a PostModern World. Albany: State University of New York Press. 
Relph, E. 1976. Place and Placelessness. London: Poin Publishers.

Schatzki, T. 2002: The Site of the Social. University Park, PA: Pennsylvania University Press

Shalem, Y. \& S. Pendlebury 2010. Retrieving Teaching: Critical Issues in Curriculum, Pedagogy and Learning. Lansdowne: Juta \& Co Ltd.

Tuan, Y. 1977. Space and Place: The Perspective of Experience. Minneapolis, MN: University of Minnesota Press.

Tuck, E. \& K.W. Yang 2012. Decolonisation is not a Metaphor. Decolonisation: Indigeneity, Education and Society 1, 1: 1 - 40.

Tyler, R.W. 1949. Basic Principles of Curriculum and Instruction. Chicago: The University of Chicago Press.

Van Harmelen, U. 1999. Where has all the Geography Gone? A Social Constructivist Perspective of Curriculum 2005. South African Geographical Journal 81, 2: 80 - 85.

https://doi.org/10.1080/03736245.1999.9713666

Wesso, H. \& S. Parnell 1992. Geography Education in South Africa: Colonial Roots and Prospects for Change. In Robertson, C. \& J. McCarthy (eds.): Geography in a Changing South Africa. Cape Town: Oxford University Press.

Woodhouse, J. \& C. Knapp. 2000. Place-based Curriculum and Instruction. Eric Document Reproduction Service No. EDO-RC-00-6.

Lesley le Grange Department of Curriculum Studies Stellenbosch University llg@sun.ac.za

Krystle Ontong Department of Curriculum Studies Stellenbosch University krystle@sun.ac.za 